E3S Web of Conferences 1, 16005 (2013)

DOI: $10.1051 / \mathrm{e} 3$ sconf/20130116005

(c) Owned by the authors, published by EDP Sciences, 2013

\title{
Mercury and Methylmercury in Southern Baltic Sea Sediments
}

\author{
M. Miotk ${ }^{1}$, J. Bełdowski $^{1}$ and J. Pempkowiak ${ }^{1}$ \\ ${ }^{1}$ Department of marine Chemistry and Biochemistry, Institute of Oceanology Polish Academy of Sciences, ul. \\ Powstańców Warszawy 55, 81-712 Sopot, Poland, michalm@iopan.gda.pl
}

\begin{abstract}
Surficial sediment samples were collected in several areas of the southern Baltic Sea during cruises of R/V Oceania in spring 2009 and 2010 for all stations and in autumn 2009 for Gdansk Deep and Gotland Deep. Samples were collected with a gravity corer. The top five centimeters of sediment were sampled by cutting it away with a plastic spatula, mixed and stored frozen $\left(-20^{\circ} \mathrm{C}\right)$ in polyethylene bags until analyses in the laboratory. Sediment cores were analysed for total mercury $\left[\mathrm{Hg}_{\mathrm{TOT}}\right]$ and methylmercury [MeHg]. Total $\mathrm{Hg}$ concentrations in sediments were between $5,81 \mathrm{ng} \cdot \mathrm{g}^{-1}$ in Odra Eustary and $225 \mathrm{ng} \cdot \mathrm{g}^{-1}$ in Gdansk Deep. Lowest concentration of methylmercury were recorded in Odra Estuary; $61,29 \mathrm{pg} \cdot \mathrm{g}^{-1}$. Highest concentration of $\mathrm{MeHg}$ were found in Vistula Estuary, 940,07 $\mathrm{pg} \cdot \mathrm{g}^{-1}$.
\end{abstract}

Key words: mercury, methylation, methyl mercury, sediment, Baltic Sea

\section{Introduction}

Environmental contamination by mercury is a worldwide problem. It is important to assess the possible effects of increasing levels of environmental mercury pollution on human health and the environment (Liao et al., 2006). Mercury $(\mathrm{Hg})$ is a potent toxic substance, the toxicity of which is elicited at very low concentrations. Although all chemical forms of mercury are toxic, public health concerns are focused on methylmercury (MeHg). Methylmercury is a neurotoxin that causes pathologies ranging from mild numbness of the extremities to blindness, loss of balance, and in severe cases, death (Barkay and Wagner-Dobler, 2005). In the marine environment mercury, owing to its affinity for particulate matter, is readily scavenged from the water column (Laurier et al., 2003) and transferred to bottom sediments (Cossa and Gobeil, 2000).

The aim of this study was to demonstrate levels of total mercury and methylmercury concentrations measurements in sediment samples collected in southern Baltic Sea.

\section{Materials and Methods}

Surficial sediment samples were collected in several areas of the southern Baltic Sea during cruise on the R/V Oceania in spring 2009 and 2010 for all stations and in autumn 2009 for Gdansk Deep and Gotland Deep. Location of the sampling stations are shown in Figure 1. Samples were collected with a gravity corer. The top five centimeters of sediment was sampled by cutting it away with a plastic spatula, mixed and stored frozen $\left(-20^{\circ} \mathrm{C}\right)$ in polyethylene bags until analyses in the laboratory.

Before analysis all the sediment samples were freeze-drying and homogenized. Total mercury determination were performed via pyrolysis where the trap is heated in a stream of oxygen (Leco AMA 254). The AMA254 technique of direct combustion features a combustion/catalyst tube that decomposes the sample in an oxygen-rich environment and removes interfering elements. A gold amalgamator trap collects all mercury from the evolved gases and a dual-path length cuvette/spectrophotomer specifically determines mercury over a wide dynamic range.

For methylmercury the following procedure for sample preparation and extraction was used (Quevauviller et al., 2000; Logar et al., 2000; Liang et al., 1994). Methyl mercury defined by this procedure includes all monomethyl mercury forms and species found in sediments (e.g. $\mathrm{CH} 3 \mathrm{Hg}+, \mathrm{CH} 3 \mathrm{HgCl}$, $\mathrm{CH} 3 \mathrm{HgOH}$, and $\mathrm{CH} 3 \mathrm{HgS}-\mathrm{R})$, which are amenable to complexation and extraction as $\mathrm{CH} 3 \mathrm{HgBr}$. The use of the pre-extraction procedure eliminates any interference from organic matter, particulate, and sulphides, and strongly reduces the positive analytical artefact generated by the interaction of ambient inorganic mercury with organic compounds (especially humics) in the samples (Hintelmann,1999). To wet sediment were sequentially added a $1.5 \mathrm{M} \mathrm{HBr}$ solution and $1 \mathrm{M} \mathrm{CuSO} 4$. When the effervescence ceased, $\mathrm{MMHg}$ was extracted into $\mathrm{CH} 2 \mathrm{Cl} 2$. Organic phase was collected into a teflon vial containing 
$20 \mathrm{ml}$ of Milli-Q water, the vial was heated at $80 \mathrm{C}$ and finally purged with $\mathrm{N} 2$ until all $\mathrm{CH} 2 \mathrm{Cl} 2$ had been volatilised out. After dilution to a known volume with reagent water, analysis was carried out by aqueous phase ethylation. By purging the sample with $\mathrm{N} 2$, ethyl methyl-mercury was transferred to a Tenax trap and then analysed by using the GC/pyrolysis/CVAFS technique.

\section{Results and Discussion}

Mercury content in surficial sediments from southern Baltic Sea is typical for this kind of seas. In collected samples following concentration of total mercury ranges were observed: Gdansk Deep 161,72 (spring 2010) - 225,18 $\mathrm{ng} \cdot \mathrm{g}^{-1}$ (spring 2010); Gotland Deep 102,38 (autumn 2009) - 148,21 ng. $\mathrm{g}^{-1}$ (spring 2009); Bornholm

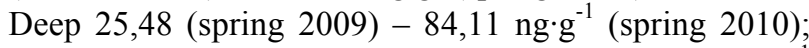
Vistula Estuary 17,37 (spring 2009) - 152,88 $\mathrm{ng} \cdot \mathrm{g}^{-1}$ (spring 2010) and Odra Estuary 5,81 (spring 2010) $12,87 \mathrm{ng} \cdot \mathrm{g}^{-1}$ (spring 2009). Highest mean values of total $\mathrm{Hg}$ was recorded in sediments from Gdansk Deep in autumn $2009\left(196,18 \mathrm{ng} \cdot \mathrm{g}^{-1}\right)$ while the lowest value recorded in Odra Estuary in spring $2010\left(7,79 \mathrm{ng} \cdot \mathrm{g}^{-1}\right)$
(Fig. 1). Very similar situation was reported in Kannan and Falandysz (1996) research. Authors recorded concentrations in coastal marine sediments in the range of $37-312$ (mean 163) $\mathrm{ng} \cdot \mathrm{g}^{-1}$. In comparison with the Mediterranean region, Baltic Sea is only slightly contaminated area. Concentration of total mercury in this region ranged $0,10-22,30 \mu \mathrm{g} \cdot \mathrm{g}^{-1}$ (Covelli et al., 2000).

The present study showed also levels of methylmercury concentrations in sediments from southern Baltic Sea. The highest mean value were located in Vistula Estuary in spring $2010\left(626,71 \mathrm{pg} \cdot \mathrm{g}^{-1}\right)$. Others mean values ranged from $80,63 \mathrm{pg} \cdot \mathrm{g}^{-1}$ (Vistula Estuary, spring 2009) to $375,25 \mathrm{pg} \cdot \mathrm{g}^{-1}$ (Gdansk Deep, spring 2010) (Fig. 2). Previous studies of methylmercury in this area showed similar level of contamination in coastal sediments. Kannan and Falandysz (1996) reported that methylmercury ranged from 35 to 250 $\mathrm{pg} \cdot \mathrm{g}^{-1}$.

Figure 3 presents correlation between total mercury and methylmercury. Positive correlation (coefficient is 0,7549) showed that in southern Baltic Sea sediments conditions are favoring mercury methylation.

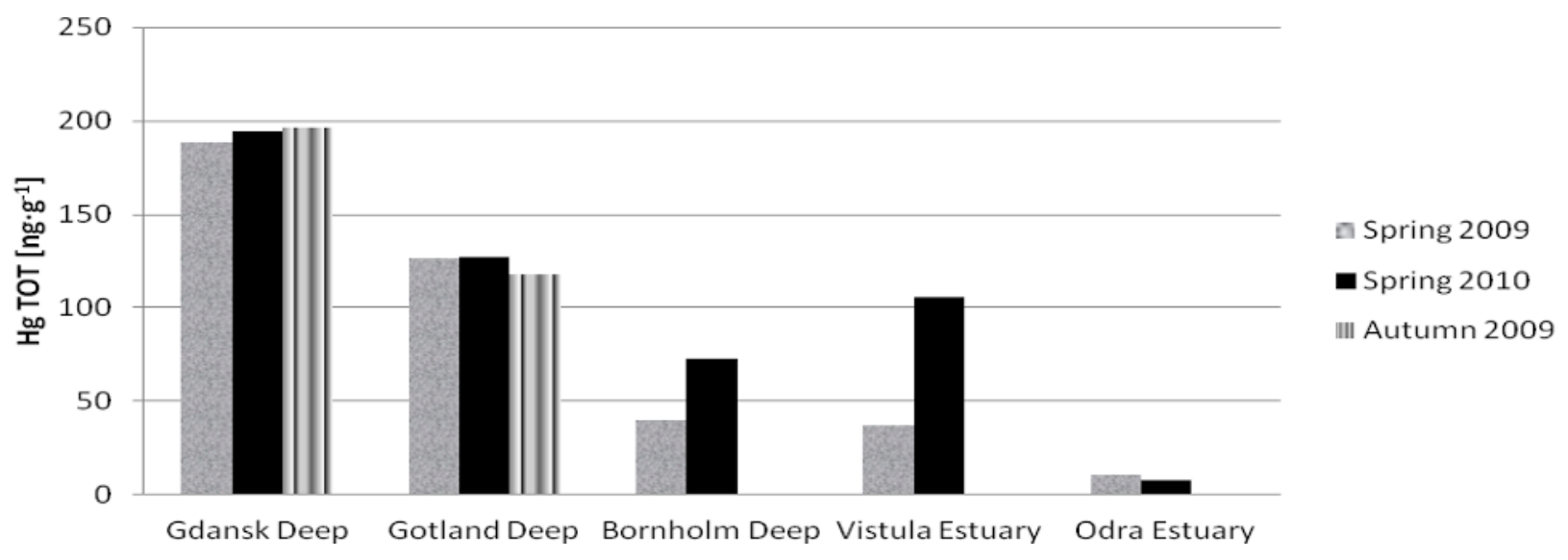

Fig. 1. Mean values of total mercury concentrations in southern Baltic Sea sediments.

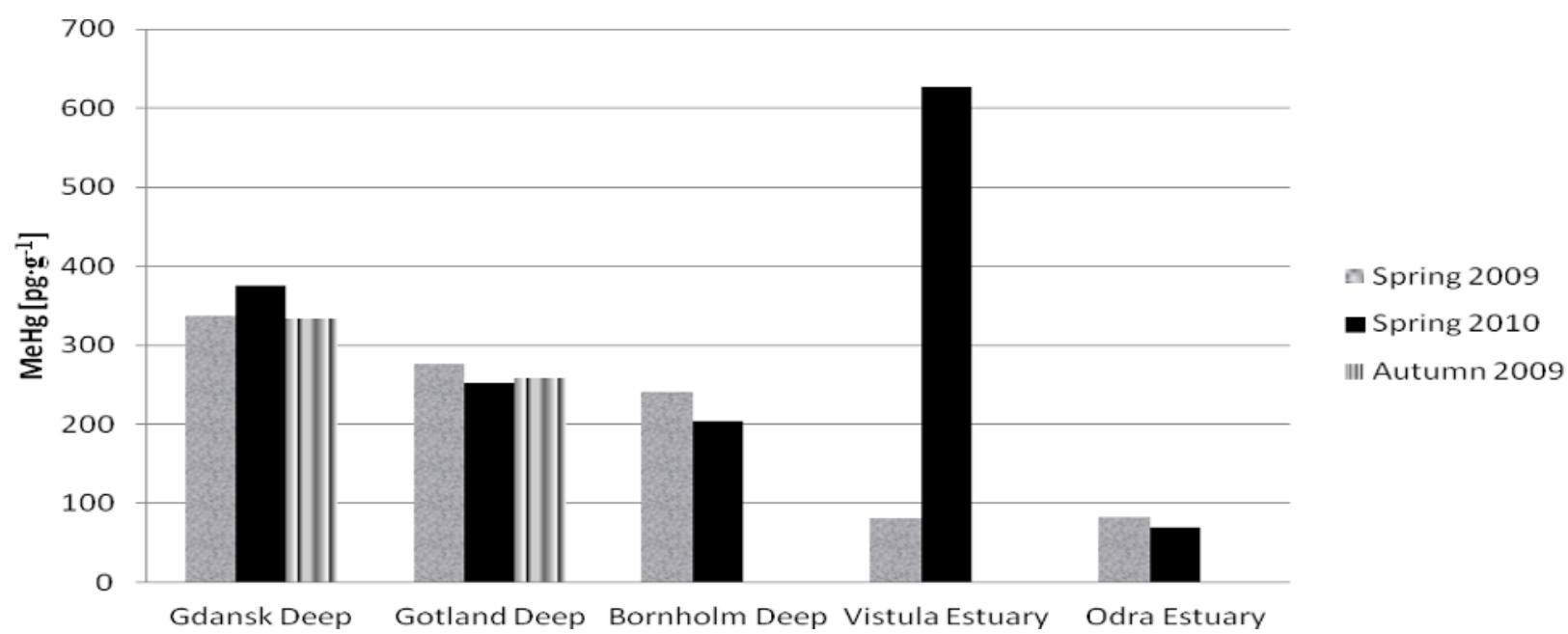

Fig. 2. Mean values of methylmercury concentrations in southern Baltic Sea sediments. 


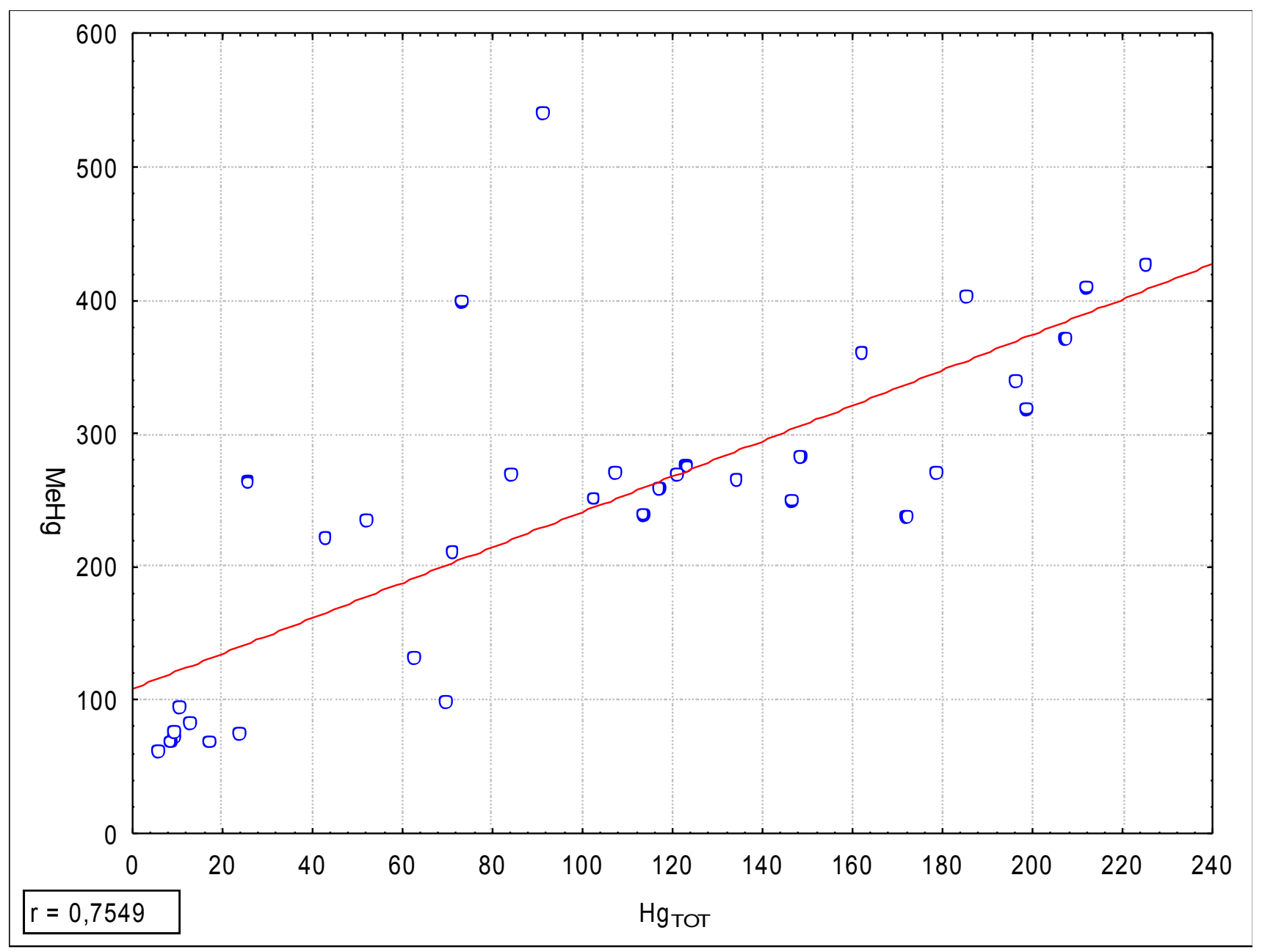

Fig. 3. Relationship of methyl mercury with total mercury in southern Baltic Sea sediments.

\section{Conclusion}

Mercury is highly toxic metal, especially methylmercury. Present studies showed that levels of $\mathrm{MeHg}$ in sediments are significant. That is the reason why further studies concerning mercury speciation and discharge to the coastal zone are essential.

\section{References}

Barkay W., Wagner-Dobler S. (2005), Heavy metals in marine sediments of Taranto Gulf (Ionian Sea, Southern Italy), Marine Chemistry 99: 227 - 235

Cossa D., Gobeil C., (2000). Mercury speciation in the lower St. Lawrence estuary. Can. J. Fish. Aquat. Sci., 57 (Suppl. 1): 138-147

Covelli S., Faganeli J., Horvat M., Brambati A. (2000), Mercury contamination of coastal sediments as the result of long-term cinnabar mining activity (Gulf of Trieste, northern Adriatic sea), Applied Geochemistry 16 (2001) 541 \pm 558

Kannan K., Falandysz J. (1996) Speciation and
Concentrations of Mercury in Certain Coastal Marine Sediments, Water, Air, Soil Pollution, Volume 103 (1) Springer Journals - Apr 1, 1996

Laurier, F. J. G., Mason, R. P., Whalin, L. and Kato, S. (2003). Reactive gaseous mercury formation in the North Pacific Ocean's marine boundary layer: a potential role of halogen chemistry. J. Geophys. Res. 108(D17), 4529, oi:10.1029/2003JD003625.

Liang, L., Horvat, M., Bloom, N.S., (1994). An improved speciation method for mercury by GC/CVAFS after aqueous phase ethylation and room temperature precollection. Talanta $41,371 \pm 37$

Liao V. H.-Ch., Chien M.-T., Tseng Y.-Y., Ou K.-L. (2006), Assessment of heavy metal bioavailability in contaminated sediments and soils using green fluorescent protein-based bacterial biosensors, Environmental Pollution 142: $17-23$.

Quevauviller P, Andersen K, Merry J, Vander Jagt H. (2000). Interlaboratory study to improve the quality of trace element determinations in groundwater. Analyst 123:955-957. 